\title{
EMPATHY IN TODAYS CLINICAL PSYCHOLOGY AND IN EDITH STEIN
}

\author{
A ureliano Pacciolla
}

LU M SA -H umanitas - Roma, Italy

\begin{abstract}
A bstract
The purpose of this article is to offer the possibility of approaching the empathy understood by the contemporary clinical psychology represented by the DSM-5 (2013) with the empathy understood by the phenomenological phiIosophy represented by Edith Stein (1916). It will be possible to consider how the philosophical intuitions have anticipated for a century what the neurology has later discovered with mirror neurons and that the clinical psychology has then codified in the functioning of the personality. The empathy understood by Edith Stein is almost completely synthesized in the constructs of empathy, intimacy and identity of the DSM-5. Practical exercises are proposed through three schemes and two short questionnaires to develop empathy and to continue further research. These are tools based on the DSM-5 criteria to evaluate the functioning of the personality and the degree of problematic of an individual. Knowing some criteria and tools to develop empathy is useful not only to psycho therapists but also to formators and spiritual directors. The study of empathy and its development on a personal, couple, group and social level can certainly contribute to growth only on the psychological, but also moral and political.
\end{abstract}

Key W ords: 1. Empathy 2. Intimacy 3. Identity 4. Personality 5. Spirituality 6. Mirror neurons.

\begin{abstract}
A bstrak
Tujuan dari artikel ini adalah untuk menawarkan sebuah kemungkinan untuk memahami empati sebagaimana yang dipahami oleh Psikologi Klinis Kontemporer yang diwakili oleh DSM-5 (2013) dengan empati sebagaimana yang dipahami oleh Filsafat Fenomenologi yang diwakili oleh Edith Stein (1916). Merupakan hal yang masuk akal untuk mempertimbangkan bagaimana intuisi filosofis telah seabad lebih dulu menyadari hal yang oleh Neurologi kemudian disebut sebagai M irror Neurons dan Psikologi Klinis kemudian memasukkannya ke dalam Fungsi Kepribadian. Empati sebagaimana yang dipahami oleh Edith Stein hampir seluruhnya disintesiskan dalam konstruksi empati, intimasi dan identitas menurut DSM-5. Latihanlatihan praktis ditawarkan melalui tiga skema dan dua kuosioner pendek untuk mengembangkan empati dan untuk melanjutkan penelitian kearah yang lebih
\end{abstract}


jauh. A lat-alat seperti skema dan kuosioner ini didasarkan pada kriteria DSM5 untuk mengevaluasi fungsi kepribadian dan tingkatan permasalahan individu. Mengetahui beberapa kriteria dan alat untuk mengembangkan empati tentu saja sangat berguna tidak hanya bagi psikoterapis tetapi juga bagi para formator ataupun pembimbing rohani. Studi tentang empati dan pengembangannya pada level personal, pasangan, kelompok dan sosial tentu saja tidak akan hanya berkontribusi pada perkembangan psikologi, namun juga pada moral dan politik.

Kata Kunci: Empati, intimasi, kedekatan, kepribadian, spiritualitas, cermin neorons.

\section{Introduction}

A first objective of this article is to hypothesize a parallelism between: 1) the definition and role of empathy in the DSM-5 (2013) as an authoritative point of reference for all clinicians and researchers in the world; 2) philosophical reflections on empathy by Edith Stein (1916) as an authoritative reference point for the phenomenological approach both in its epistemological principles and in its possible applications. The second objective of this article is to start a debate to find convergences or complementarities useful for human growth as understood in the humanistic-existential approach of contemporary psychology. Future researches can show more interpretations and applications of empathy (as intended by DSM -5 and by E. Stein) to any kind of professional help: psychotherapy or spiritual guidance or in the socio-political contest or in the friendship relation.

The third objective is to provide practical exercises for the development of empathy as understood both by the clinical criteria of DSM-5 and by the criteria of phenomenology of which Edith Stein is among the most valid representatives in philosophy. In the conclusion we will give a reference to the neurophysiological basis of empathy: mirror neurons.

\section{Empathy In the DSM-5}

In DSM-5, empathy is one of four dimensions for assessing personality functioning. All four dimensions (identity, self-direction, empathy and intimacy) for the functioning of the personality are structured in the form of a "scale" to assess the degree of impairment of functioning. In each of the aforesaid four dimensions, we start from a level of zero impairment (level of normality or resilience due to the absence of a significant impair- 
ment) up to a level four (the maximum of impairment of personality functioning).

The DSM-5 does not give a true definition of empathy but - as it should be - only inclusive components, in the sense that other components can also be included, in addition to those given. Empathy here is understood as innate psychophysiological competence but to be developed in view of personal and social maturity. It is very important to note that the DSM-5 places the empathy for the evaluation of the "inter-personal" functioning of the personality. That is exactly what E. Stein did in 1916, in her doctoral dissertation.

Now let us observe how the DSM-5 considers empathy in its three components without clinical impairmentand then empathy with its and the three components with a level 1 of impairment. ${ }^{1}$

\section{EM PATHY}

Level O-Little or no Impairment: He/ She...

a) Is capable of accurately understanding others' experiences and motivations in most situations.

b) Comprehends and appreciates others' perspectives, even if disagreeing.

c) Is aware of the effect of own actions on others.

Level 1-Some Impairment: $\mathrm{He} /$ She ...

a) Is somewhat compromised in ability to appreciate and understand others' experiences; may tend to see others as having unreasonable expectations or a wish for control.

b) Although capable of considering and understanding different perspectives, resists doing so.

c) Has inconsistent awareness of effect of own behavior on others.

1 For completeness we report the other levels of impairment of empathy according to the DSM-5 (APA, Washinghton, 2013).

1 Moderate impairment

a) Is hyper-attuned to the experience of others, but only with respect to perceived relevance to self.

b) Is excessively self-referential; significantly compromised ability to appreciate and understand others' experiences and to consider alternative perspectives.

c) Is generally unaware of or unconcerned about effect of own behavior on others, or unrealistic appraisal of own effect.

2 Severe Impairment

a) A bility to consider and understand the thoughts, feelings, and behavior of other people is significantly limited; may discern very specific aspects of others' experience, particularly vulnerabilities and suffering.

b) Is generally unable to consider alternative perspectives; highly threatened by differences of opinion or alternative viewpoints. 
It is important to note that the empathy described here is aimed at clinical evaluation in view of a treatment and therefore we should not expect languages and references typical of other disciplines such as philosophy, morals or other disciplines, even if - as we shall see - they will to be much more correlations than one might think in various areas of human knowledge and applications.

From a personal point of view I believe that this consideration of empathy in clinical terms can be completed by the consideration of another construct of the same DSM-5, also considered in the evaluation of the functioning of the personality from an inter-personal: intimacy.

The intimacy in the DSM-5 completes, widens and deepens the construct of empathy. Precisely because here intimacy is not understood in close correlation necessary with sexuality, precisely for this it is worth considering it, at least in its three components at the zero impairment level: (DSM-5, pp. 775-776)

\section{INTIMACY}

Level 0-Little or no Impairment: He/ She...

a) Maintains multiple satisfying and enduring relationships in personal and community life.

b) Desires and engages in a number of caring, close, and reciprocal relationships.

c) Strives for cooperation and mutual benefit and flexibly responds to a range of others' ideas, emotions, and behaviors.

Level 1-Some Impairment: $\mathrm{He}$ / She...

a) Is able to establish enduring relationships in personal and community life, with some limitations on degree of depth and satisfaction.

b) Is capable of forming and desires to form intimate and reciprocal relationships, but may be inhibited in meaningful expression and sometimes constrained if intense emotions or conflicts arise.

c) Cooperation may be inhibited by unrealistic standards; somewhat limited in ability to respect or respond to others' ideas, emotions, and behaviors.

c) Is confused about or unaware of impact of own actions on others; often bewildered about peoples' thoughts and actions, with destructive motivations frequently misattributed to others.

3 Extreme Impairment

a) Has pronounced inability to consider and understand others' experience and motivation.

b) Attention to others' perspectives is virtually absent (attention is hypervigilant, focused on need fulfilment and harm avoidance).

c) Social interaction can be confusing and disorienting. 
As can be easily observed, the joint consideration of empathy and intimacy can provide very relevant indications not only from the clinical point of view but also social, moral and philosophical.

The above criteria on empathy and intimacy can be transformed into items for a self-administered questionnaire and an observation questionnaire aimed at both greater awareness of one's own empathy and also aimed at personal and social growth of the same empathy. This will be shown in paragraph 4 of this article on the clinical applications of empathy.

Just as in the clinic we need to integrate but distinguish empathy with intimacy, in the same way we need to distinguish empathy from others on correlates, including: collaboration, metacognition, sharing, identification, participation, entanglement, fusion, projection, fusion ... (2).

Since empathy does not mean identifying with the other, then it will be important to clarify the construct of "identity" in order to differentiate it and to have criteria on how to be empathic while maintaining its identity.

\section{IDENTITY}

Level of Impairment 0-Little or no Impairment: He/ She ...

a) Has ongoing awareness of a unique self; maintains role-appropriate boundaries

b) Has consistent and self-regulated Positive self-esteem, with accurate selfappraisal.

c) Is capable of experiencing, tolerating, and regulating a full range of emotions.

Therefore, being very empathetic does not imply a depersonalization with diminution or loss of one's identity. It is exactly the opposite. A uthentic empathy involves continuing to be oneself with a different way of feeling the other.

\section{Empathy In Edit Stein: Definitions}

Why take Edith Stein into account in considering empathy in a clinical psychology context?

2 Other possible distinctions should be made between empathy and some clinical self-discipline and self-regulation activities; among these: mindfulness, meditation, the contemplation [of nature (which is empathizing in nature: hineinfühlenunsererselbst)]. 
The first reason that leads us to consider Edith Stein in this context is because she was the first to do a complete philosophical analysis of empathy, at least duringher time in 1916.

The second reason for me to consider Edith Stein in a context of clinical psychology is for her phenomenological approach that has given a turn to the consideration of science, in particular - in this case - re search and applications of psychology ${ }^{3}$.

Finally, I think the consideration of empathy cannot be reduced to clinical research alone without the contribution of other disciplines such as philosophy, sociology, neurology and ethology.

The methodology that E. Stein uses in the treatment of empathy is clearly phenomenological and therefore we should not expect the same schematism that we have considered in the DSM-5 clearly distinguishing the three components of empathy in integration with the three components of intimacy and distinguishing the three components of identity.

E. Stein of course, does not intend to give criteria for the diagnosis and treatment of mental disorders but only to elaborate a path to the ego and to us. This passage from the "I" to the "we" is very important for the diagnosis and treatment of personality disorders. Here Stein can give us an original contribution 4 .

Edith Stein studied empathy [Einfühlung] in order to "clarify the phenomenological source of one's own body, soul, individual, spiritual personality, social community and community structure" 5 .

In the premise of her thesis E. Stein states:

"To fully understand the essence of the empathic act, we make this example: a friend comes to me and tells me he has lost a brother and I realize his pain.

3 In this context, I would like to mention only the importance of the phenomenological approach as opposed to the rationalist and positivist approach in which human phenomena could and should be reduced to matter to be measurable and controllable. Thanks to the phenomenological breakthrough (inaugurated by Husserl and continued by E. Stein) we have new approaches to psychology in USA with C. Rogers, A. Maslow, G. Allport. A mong the main representatives of the phenomenology in psychiatry, psychology and psychotherapy there is V. Frankl. Thanks to these premises, then we have in Italy the psychiatric revolution in the '80s with Basaglia and then with V. Guidano the current humanisticexistential approach.

4 We must remember that personality disorders were initially included in Axis-II of the DSM-III (1980) and have undergone changes in the subsequent editions of the DSM.

5 In the Greek theater, originally, the meaning of «Empàtheia» was emotional participation between the singer and his audience. Edward Titchener (1867-1927) translated for the first time "einfühlung" with "empathy". The object of Einfühlung (empathy) is expressed in the form of the symbolic relation (as psychologist Theodor Lipps, 1851-1914 al ready stated) and therefore the reflection on the empathic act is inserted into this broader context (Edmund Husserl, Giudiziosulladissertazione di laureadella sign. Stein in Edith Stein, II problema dell'empatia, a cura di Costantini, Elioe Schulz, Peter, ed. Studium, Roma 2003, 29 - 30). 
What has made me come this awareness? Due to the cause of this pain, I would not like to deal with it. What I would like to know, however, is what is in itself such this awareness and not by what means it is possible to reach it". [the underlined is mine] ( $\left.{ }^{6}\right)$.

In order to understand even better the thought of Stein about empathy we need to consider some others philosopher such as Edmund Husserl, Theodor Lipps and Max Scheler. Some main differences between E. Husserl and E. Stein on empathy.

According to Edmund Husserl Empathy makes communication possible between subjects that are distinct but not isolated, supportive and autonomously personal and bound not only on a logical level.For Edith Stein, the phenomenology of empathy is the basis for demonstrating the phenomenology of the person, of one's body, of the soul, of the spiritual, of the individual in general and of the social and community structure. $\mathrm{E}$. Stein begins phenomenological personalism characterized by the intrapersonal description connected with the inter-personal description.

Through empathyEdmund Husserl reaches the knowledge of an objective world and arrives at God; Edith Stein comes to the knowledge of the alien consciousness and arrives first to the other and then to God. If the empathy remains in the realm of pure reason it is pure speculation or only knowledge. Empathy - in the context of its practical reason - becomes performative and formative.

The empathy hypothesized by Edith Stein allows us to:

1. To know one's own identity (I cannot know myself without knowing others).

2. To be collaborative and experience intimacy (I cannot know others if I do not know myself).

3. To go beyond our perceptions and get to know each other but it is not possible to suffer in place of another.

4. The opposite of empathy is indifference (towards needs, interests, purpose opinions, emotions of others). On one side it is not possible to suffer in place of another andon the other side empathy is an interior participation in foreign experiences, in the experience lived by others. So, empathy it is an etero-centered act that clarifies better our own identity ${ }^{7}$.

The affinity between internal perception and empathyis explained

6 E Stein, Zum problem der Einfühlung, Niemeyer, Halle 1917, Reprint der OriginalausgabeKaffke, München 1980, trad. it. II problema dell'empatia, trad. di Costantini, ElioeSchulz, Peter, Studium, Roma 1985, 19982, al so M. Nicoletti (Eds) FrancoA ngeli Milano 1986, 20022, pp. 71-72

7 Idem, p. 80. 
by Stein with the possibility of being able to deceive the loved one, but never on the love itself for her ${ }^{8}$.

For Stein, (endosensation) is possible thanks to:

a) The fusion between internal perception and external perception;

b) The possible multiple collocation of one's own body in space;

c) The possibility of changing (at least in the imagination) position and characteristics of the body.

The function of empathy understood as reliving and accompanying is above all a cognitive methodological instrument of psychology: as we know ourselves through self-observation, so we know others through empathy.

In fact, from the large size of one's hand, which is not given to me as fixed, it is possible to empathize the hand of a child or a woman. For Lipps the goose bumps or bluish nose do not need to be further explained because it is evident that signs indicate how the subject is cold.

E. Stein does not believe that an expression is always reveal ed on the face (perception of psychic manifestation). It is possible that a coldis not the real cause. We need to differentiate the role of "endosensation" from the process of empathy.

Empathy as an interior participation in foreign experiences is discussed through the metaphor of the acrobat. I am not a single being with the acrobat, but I am only "near" him; I do not really do his movements, but "almost", that is to say not only do not perform the movements from the outside (as Lipps said) but what inwardly corresponds to the movements of the body proper - that is, the I live - it is not native to me, but is non originating'. This way of understanding empathy does not limit, rather expands freedom and confirms one's identity. That because thanks to his conscience (awareness), the human being can grasp the lived experience of others.

The empathized joy I have is of the same content of the joy that is grasped.

In the event that the joy of promotion is the prerequisite for the cojoy of taking a trip together, then the problem of the subjective and objective relevance of the success of the other will arise.

E. Stein considers also the negative empathy, the correction of empathical acts, and the possibility of misleading and deception of

8 Reported by G. Lo Russo, L'empatia alle sue origini. II solco tracciato da Edith Stein, Edizioni Demodel, Arlon - Belgium, 2018. p. 39.

9 E.Stein, II problema dell'empatia, cit., p. 87. 
empathy.The case of negative empathy is represented with an example. If Tizio gives joyous news to Caius and the latter is saddened by some serious event that has happened to him, the pain prevents the latter from feeling the joy of Tizio. (The experience of joy meets with the experience of pain can be counteracted or neutralizedamong them) ${ }^{10}$.

The meaning of a situation can appear better through gradual empathic acts. A nother example is: Seeing a wound on Tizio's body, Caius feels the pain but, seeing, simultaneously, a smile appears on Tizio's face, Caius needs another empathic act to correct the first conclusion.

By resorting to an act of empathy, one can find that the man feels the pain and that, perhaps by perversion, he actually enjoys the suffering. Or maybe he simply does not give up in the face of suffering, but can quietly hide it. So how to solve the dilemma? By correcting the empathic act. Only in this way will one succeed in discerning an authentic expression from one that is not ". So, empathy can also be misleading although there is always the possibility of correction of empathical acts.

To avoid deception, one must use experiences of one's own type and not one's own constitution:

"One cannot assign to a child one's own judgment, or hope that a color-blind person has the same color impressions. etc. However, it will be necessary to remember that empathy does not mean understanding of the others psychic life. So how can we solve the problem of deception? Through other acts of empathy! If, for example, the same enjoyment in listening to a symphonic concert is emphatized in Tizio, through another act of empathy, one can deduce that in reality Tizio does not experience the same enjoyment, but is bored to death. Hence the need to empathize without taking into account their sensations and situations, but only of their own ego as such ... Every single person is a type that arises in a gradation of types from the bottom up. At the bottom we find the common and generalized type obtainable from the personal data, from sex, from social position, etc. The spiritual person who lives a value is revealed above. In fact, if it does not correspond to a high degree of one's own typology, one cannot understand, for example, the sacrifice of a believer who gives his life for faith" ${ }^{(1)}$

\section{Empathy By Edith Stein: Applications}

Obviously, we cannot expect from a philosopher direct clinical instructions or applications but the possible epistemological applications that E. Stein can give us about empathy will certainly help clinicians, at least those with a phenomenological background. It is the case of: mental anomalies and psychic anomalies, the gap and the link from feelings to

10 Reported by G. Lo Russo, p. 33.

11 Idem, 59; 70. 
values, the psychological moment, resilience, personality and gradation of types, the body and the will, medical-patient empathization and the spiritual dimension.

Let us consider, at least briefly, these aspects of empathy above all with the examples that E. Stein brings. In fact, her philosophical Ianguage is not always easy to access to clinicians.

In mental anomalies, the rational laws of the psychic are completely deactivated. (E.g., by a rational law, one is more troubled by the rude message given by a friend than by learning that the earthquake killed thousands in a given nation). In psychic abnormalities (anesthesia, aphasia) the comprehension and empathy of the others psychic life is not disturbed. As for psychoanalysts, the difference between neurosis and psychosis: the first is curable, the second is not. Some pathological facts do not interfere neither on the psychic life in a continuous way, nor on the legality of reason: for ex. a depression caused by bad news. Frankly, however, it is not known to what extent one can speak of pathology.

The correlation between values and personality: From the way in which the diffusion and penetration into the ego of feelings is realized, the scale of values is born in which, as one moves forward simultaneously, one becomes more and more masters of one's personality. The feeling of pain that comes with the loss of a watch cannot be compared to that of the loss of a dear friend. The former affects superficially in the ego, the latter does it in a more incisive manner.

The state of mind always has a correlation with an external sentient act: the news has made him/ her furious. Depending on the scope of this sentient act, the range of action of the consequent state of mind gradually increases or decreases.

What nowadays is called resilience is linked to the spiritual dimension: It is the case of people who, despite suffering numerous environmental and physical conditioning in a negative sense, are able to overcome these difficulties and gain a very positive spiritual behavior diametrically opposed to their material condition ${ }^{12}$.

Empathy by Stein can be expressed mostly through body, will and spirituality.

The hand cannot touch itself, the eye does not allow self-seeing ... the ego coming out of its skin, is able to see its body touched with the feet attached to the vault of the room. The body is a medium that manifests its interiority and is the bridge that allows us to grasp the interiority of others. The will, even if not absolutely, is able to predominate both on the

12 Reported by G. Lo Russo, pp. 63-65; 68. 
body and on the soul. Naturally, the will has limits:"The soul has no interest in making a climb and the body, on the other hand, is too tired. In this case the action does not proceed because the will has not been victorious, even if it must be remembered that only the volitional ego is the effective master of the proper body".

Fantasy can build emotions related to the body:

“The worker who, being unable to do anything against his employer, with his imagination has al ready stabbed him several times. In other cases, it may happen that you find yourself expressing joy after building a beautiful castle in the air. If it is true that feelings can influence the reproduction of representations, it is also true that, with a certain exercise, it can be made that this reproduction can be modified according to one's own desire; you can, for example, avoid becoming red in order not to understand, to those in front of you, your own feeling of shame ... the redness of the face can depend on shame, but also on making an intense effort, from an excess of anger or none of these things ... yet an excess of anger is a sign of a qualitatively and substantially violent psyche» ${ }^{13}$.

Some aspect of empathy in the medical-patient relationship is considered with some other examples: It is also possible to have a fractured arm and a very good general state of health or, on the contrary, to feel very sick despite having no pain. To solve this clinical problem, the doctor observes the patient's face, empathizes his state of health and, thanks to his experience, manages to diagnose the disease. Empathize with one's own body: "A child who, after playing and jumping, feels lost due to excessive exhaustion and emphatizes his state, cannot but feel a certain nervousness" (p.55)

The spiritual dimension by E. Stein can be one of the most difficult aspect for some clinicians. Nevertheless, this is one peculiarity of the phenomenological approach and one difference between the humanistic-existential of contemporary psychology.

"The spiritual has an interiority in a sense absolutely unknown to what is material and extended. If it exits itself, this externalization can occur in many ways: as a turning to objects (what Husserl calls intentionality of the life of the spirit), as a purely spiritual opening to alien spirits, and as a penetration into them in order to understand and participate in their spiritual life; but also as a true structuring in space [...] yet remaining in itself"14.

For Stein, the soul and the spirit together form the interiority of man and also empathy implies a relationship between language, emotion and

13 Idem, pp. 46-48.

14 E. Stein, Endliches und ewiges Sein. V ersucheinesA ufstiegszum Sinn des Sein (ESW II), hrsg. von L. Gelber und R. Leuven, Nauwelaerts-Herder, Louvain-Freiburg 1950, trad. it. Essere finito e essere eterno. Per una elevazione al senso dell'essere, trad. it. di Luciana, Vigone, rev. di Ales Bello, Angela, Città Nuova, Roma 1988, p. 255. 
mimic expression. Language combined with mimic expression refers to the intimacy of the person, and not only that, is a vehicle of great importance for teaching.

«In addition to the concomitant manifestations of feelings [...] the expression of feelings presents itself as a new phenomenon. I blush with shame, I clench my fists when I'm angry, I frown on my forehead when I'm annoyed, I moan with pain, I exult for joy... I perceive not a physical causal insurgence from psychic experiences, much less of a simple simultaneity of feeling and expression, but I feel, while I relive a feeling, as it ends in an expression or as this sprung from feeling" (page 139) ... the smile, in which my joy in the form of experience manifests itself, is given to me simultaneously as a bending of my lips; living a joy, his expression is also lived in the way of actuality "15.

Empathy also deals with expression and communication of our feelings and emotions: "To say that something is a sign means: a perceived thing tells me that there is another thing. Thus,smoke is a sign of fire. Symbol means: in a perceived thing another thing is present, and pre cisely, a psychic fact is concocted with it "(16). «If I see "the shame" in the fact "of blushing or the disappointment in that of frowning or anger in the act of clenching my fists [...] I take one thing together with the other. In the expressive phenomenon, the psyche is not co-perceived only together with what belongs to the proper body, but the one is expressed through the other, that is, the lived expression is in a relationship (as already done by Vischer and Lipps)". $\left({ }^{17}\right)$. "While the phenomena of expression appear as the emanation of sentiments, at the same time they are an expression of the psychic qualities manifested in them: a look full of anger, for example, betrays a violent character" ${ }^{18}$.

"We, as "civilized men", as everyone knows, should "dominate" us, that is, we must prevent our feelings from manifesting in an expression of our own body. In the same way we are limited in our actions and with this at the same time in our acts of will. It is true that there is still a loophole, that is, to let off steam through a "desire". The clerk who cannot show contemptuous looks to his superior, who considers him a scoundrel or a donkey, nor can he make the decision to kill him, may nevertheless wish in his heart that the devil should take him away. Or it is possible in the imagination to perform actions, which in reality we are prevented from doing. Who, having been born in disadvantaged economic conditions, cannot really realize, will give vent to his dynamism, imagining to win in battles and to perform miracles of courage. Creating another world, in which to be able to implement what is denied here, is in itself a form of expression". ${ }^{19}$

15 E.Stein, il problema dell'empatia, cit. p. 142.

16 Idem, p. 175.

17 Idem, p. 174

18 Idem, p. 140.

19 Idem, p.141. 
The inner life of the subject does not consist only in the psychic life made up of feelings, emotions, etc., but also in the spiritual life formed by freedom, will. These characterize the subject, with respect to all other living beings, as a free person capable of self-determination. This spiritual dimension of the inner life is closely related to the body in the same way as the psychic: "a penetration of the spirit into the physical world, a visible becoming of the spirit in the body proper made possible through the psychic reality" 20 .

"Action is always a creation of something that is not there. At the fiat of the volitional decision corresponds the "fieri" of the wanted and the "facere" of the volitional subject in action. This action can be a physical action: I decide to climb a mountain and implement this decision. The action, as the fulfillment of the will, results to be totally determined by the will ". «The volitional act has not only an objective correlative - the wanted - before it but, while it releases itself from itself, the action confers a reality to the desired and becomes creative. The whole of our world of culture, all that the human hand has formed, all the objects of use, all the works of craftsmanship, technology and art are related to the spirit that has become reality ". ${ }^{21}$ "The will uses the psychophysical mechanism to accomplish and achieve what is wanted, just as the sentiment uses the same mechanism to realize its expression"22.

The will belongs to the conscience and therefore is not subject to a rigid determinism. The will uses a psycho-physical mechanism to express itself and act through the body but does not depend on this mechanism, rather it dominates it.It is a "set-up of the machine". "I decide to take an exam and the necessary preparations are done automatically. It may happen that my forces fail even before the goal is reached; in this case every necessary mental activity must now be recalled in life, overcoming a strong contrary tendency through an act of will. Thus, the will has its dominion both on the soul and on the body proper, even if not in an absolute way and not without experiencing a refusal of obedience $»^{23}$

Thewill indirectly manifests thespiritual dimension and makes greater empathic understanding possible. "Personal life, which expresses itself in a manual gesture, shows behind everything that shows, to the characters of writing, to the signs, the brush or hammer (similarly the products of thought contain, in addition to their objective content, traces of inner spontaneity, to which they owe their existence). The whole world, of

\footnotetext{
20 Idem, p.196.

21 Idem, p.196.

22 Idem, p.145.

23 Idem, p.146.
} 
which an individual is concerned, bears the imprint of his personality, of his typical traits as of his personal characteristic ".24

Stein takes an example from Max Scheler, (1874-1928) to discuss how the volitional act must tend to the present by foreshadowing the future: a student has a hard task to do in the afternoon and instead prefers to engage in other less demanding activities ${ }^{25}$.

\section{Practical Exercises for the Development of Empathy}

The first step in developing empathy is the awareness of what you can do. Starting from this primary interest of E. Stein it is possible to consider each of the components of empathy envisaged by the DSM-5 and write an episode of one's life (or invent a story) that could indicate the possibility of applying that particular component. For example, the first component of empathy is: a) Is capable of accurately understanding others' experiences and motivations in most situations. The protagonist of the story should show that he possesses and can apply this ability. It is recommended to go into details both on the personality of the protagonist and on the situation. One can also dwell on the difficulties in demonstrating the applicability of the capacity in question.

Otherwise it should be done for the other three components indicated for level n. 1 of compromise (impairment). This same thing should also be done for the three components of intimacy with zero level impairment and the three components indicated for intimacy with level one impairment.

Altogether there should be 12 memories or stories about empathy and intimacy (as complementary to empathy). If there are any difficulties in finding memories of one's life or difficulty in inventing these stories, one can resort to stories of others or to classics of literature. For example, a classic of religious literature could be the parable of the Good Samaritan or other passages present in all religions and laity.

These 12 stories could be useful material for self-knowledge with the help of a psychotherapist or spiritual guide. These same 12 stories could be, at least in part, shared in pairs or in groups with others to stimulate and welcome the considerations of others and to reflect on how others have elaborated and applied the criteria of empathy and intimacy. This

24 E. Stein, Einführung in die Philosophie (ESW XIII), hrsg. von L. Gelber und M. Linssen, Herder, Freiburg i. Br. 1991, trad. it. Introduzione alla filosofia di A nna Maria, Pezzela, pref. di Angela Ales Bello, Città N uova, Roma 1998. p. 190-191.

25 G. Lo Russo cit., p. 56) M. Scheler, Essenza e forme della simpatia, edited by G. M orra, Città Nuova Roma. Edited by Boella, Franco Angeli Milano, 2012. 
exercise could be very useful in the treatment of personal disorders both in a context of individual psychotherapy, both as a couple or as a group. Obviously, this last application should be done only by psychotherapists who will have to give further indications on how to proceed.

Second Exercise. Fill the questionnaire of 16 items A and B (see the attached file $n .1$ ). This can give an idea of the self-perception of personality functioning ${ }^{26}$.

One of theBest Friend of the subject should fill a similar questionnaire (see the attached file n. 2) to have an idea of how a personality functioning can appear to others. The gap between the self-perception and the perception of others should be discussed for a better understanding of the self-perceived and others perceived empathy ${ }^{27}$.

A nother exercise is to consider what E. Stein claims about empathy and to find other links and applications to psychology. In particular we will discover many interactions between what E. Stein and V. Frankl have intuited about empathy and how their theories can help other phenomenological psychologists. This could be the subject of future research and publication.

\section{Conclusion}

Concerning the first point in my premise, we may conclude that there is enough ground for a hypothesis about a parallelism between the definition and role of empathy in the DSM-5 and the philosophical reflections on empathy by Edith Stein.About the second point, we also have showed sufficient evidence about possible convergences or complementarities on empathy (by DSM-5 and E. Stein) useful for human growth as understood in the humanistic-existential approach.

Finally, there are possible exercises to develop empathy as it is intended by DSM-5 and E. Stein.

In fact, introspection and empathy are two epistemic ways of observation: "introspection and empathy are important tools of observation for science and its theories ... psychoanalysis is a psychology of complex mental states that, with the help of introspective-empathic immersion

26 A good personality functioning is indicated by the high score to the items A and a low score to the items B.

27 When empathy has got some impairment (low scoring in the items $A$ and high scoring in the items $B$ in both empathy and intimacy (items 9-16), then we need to check the functioning in the items regarding identity (items 1-4, both A and B). All these should be done in the questionnaire in the self-perception for the personality functioning and also in the questionnaire of the others perception (that done by the Best Friend). 
prolonged observer in the inner life of man collects his data in order to explain them"28.

As mentioned, in clinical psychology, empathy is considered a natural predisposition that develops with the knowledge and experiences of the other different from one's self. It is not only the narcissistic personality disorder that is characterized by the deficit of empathy but all personality disorders - with different modes and intensities - are characterized by an impairment of empathy in the functioning of personality. As well as the clinical conditions characterized by an insufficient examination of reality can manifest itself with a compromise of empathy. This does not mean that all psychotics are unable to empathize. In my experience with sex offenders and/ or pedophiles with pedophilic disorder, I have observed that it is not al ways true that they have a metacognitive deficit and/ or a compromise of empathic functioning. Many of these subjects have good metacognitive skills and may be able to empathize in general. The clinical problem of these subjects (sex offenders and/ or pedophiles suffering from pedophilic disorder) is their functioning during sexual arousal. In other words, these subjects know how to control the impulse and how to regulate their emotions when they are far from sexual stimulation. That allows them to have a good predatory strategy. These same persons are incapable of feeling empathy during and after their sexual assault. One of the main problem of these persons is that even they know how dangerous and harmful is their own tendency, nevertheless they don't do anything to change. Individuals with pedophilic disorder know that they do not feel empathy with prepubescents because they are too much selfcentered in their own sexual urges. That is why sex offenders have good metacognition abilities in their own predatory strategy and a complete lack of empathy. Individuals with a pedophilic tendency, without acting out may increase they tendency by looking for pedo-pornography and by doing so they get closer each time to the acting on their own fantasies. If they do not stop their habit may became uncurable. We still don't know if individuals with a diagnosis of pedophilic disorder have problems in mirror neurons.

These researches require further investigations of various kinds, in particular those concerning correlations with mirror neurons.

The neurophysiological basis of empathy consists of mirror neurons that are activated both when one performs an action and when the same person sees others performing that same action. This is the basic neurophysiological mechanism to enter into relationships with others, to recog-

28 H. Kohut. La guarigione del Sé, a cura di S. Atamo Tatafiore, Ed. Bollati Boringhieri, Torino, 1980, p. 216; 263. Reported by Manganaro P., Empatia, Messaggero di S. Antonio Editrice, Padova 2014, p. 88. 
nize and understand immediately the meaning and intentions of others.

"The immediate realization, in the first person, of the emotions of others that the mechanism of specific neurons makes possible represents the necessary prerequisite for that empathic behavior that implies a large part of our interindividual relations. ... Sharing another's emotional state at a visceral-motor level is different from feeling empathic involvement in it. If we see a grimace of pain, this is not why we are automatically induced to feel compassion. This often happens but, but the two processes are distinct, in the sense that the second implies the first, not vice versa. Furthermore, understanding depends on other factors besides the re-cognition of pain: for example, from whom the other is, from what relationships we have with him, from the fact that we are more or less able to put ourselves in his shoes, that we have more or less intention to take charge of his emotional situation, his desires, his expectations" 29 .

Emotional sensations (feelings) are related to the neuronal maps of the corresponding physical state:

«When images are observed that provoke strong reactions such as fear, the body is bypassed and the brain system reproduces, simulating them, the somatic states perceived or implicit in the painted or in sculpture, just 'how-if' the body was present». ${ }^{30}$

The "as-if" circuit (as-if body loop) and the embodied simulation embodied simulation are pre-logical and automatic dynamics. ${ }^{31}$

To appreciate E. Stein's contribution to the study of empathy, one must remember that she could not know either personality disorders or mirror neurons, yet she had insights that could be useful for contemporary clinicians.On one hand most of the theory of E. Stein can be intended in the definition of empathy and intimacy as defined by the DSM5 including identity, at least for a clinical use.On the other hand, the definition of empathy given by the DSM-5 needs an epistemic deepening as that by phenomenological approach of E. Stein and that by the Existential Humanistic approach by V. Frankl.

* AurelianoPacciolla

D osen Psikologi U mum dan Kepribadian pada U niversitas Lumsa, Italia. Email: aureliano.pacciolla@ gmail.com

29 G.Rizzolati, Corrado, Sinigaglia, So quel che fai. II cervello che agisce e i neuroni specchio, Ed. Cortina, Milano 2006, p. 181.

30 A. D'Amasio, L'errore di Cartesio. Emozione, ragione e cervello umano, Adelphi, Milano, 2009.

31 D.Freedberg and Vittorio Gallese, M ovimento, emozione ed empatia nell'esperienza estetica. In Teorie dell'immagine. II dibattito contemporaneo, a cura di Andrea, Pinotti, and Antonio, Somaini Cortina, Milano, 2009, pp. 331-351. 


\section{BIBLIOGRAFI}

1. By Stein Edith:

Zum problem der Einfühlung, Niemeyer, Halle 1917, Reprint der OriginalausgabeKaffke, München 1980, trad. it. II problema dell'empatia, trad. di E. Costantini e E. Schulze Costantini, Studium, Roma 1985.

Beiträge zur philosophischen Begründ der Psychologie und Geisteswissen schaften: a) Psychische Kausalität; b)Individuum und Gemeinschaft, «ahrbuch für Philosophie und phänomenologische Forschung», vol. 5, Halle 1922, pp. 1-283, riedito da Max Niemeyer, Tübingen 1970, trad. it. Psicologia e scienze dello spirito. Contributi per una fondazione filosofica, trad. di A. M. Pezzella, pref. di A. Ales Bello, Città Nuova, Roma 1996.

Was ist Phänomenologie?, in W issenschaft/V olksbildung, supplemento scientifico al «N euen Pfälzischen Landes Zeitung», n. 5, 15 maggio 1924; è stato pubblicato nella rivista «Teologie und Philosophie», 66 (1991), pp. 570-573; trad. it. Che cosa è la fenomenologia? in La ricerca della verità - dalla fenomenologia alla filosofia cristiana, a cura di A. Ales Bello, Città Nuova, Roma 1993, pp. 55-60.

Endliches und ewiges Sein. VersucheinesA ufstiegszum Sinn des Sein (ESW II), hrsg. von L. Gelber und R. Leuven, N auwelaerts-Herder, LouvainFreiburg 1950, trad. it. Essere finito e essere eterno. Per una elevazione al senso dell'essere, trad. it. di L. Vigone, rev. di A. A les Bello, Città Nuova, Roma 1988.

W elt und Person. BeträgezumchristlichenW ahrheitstreben (ESW VI), hrsg. von L. Gelber und R. Leuven, N ewelaerts - Herder, Louvain - Freiburg 1962, trad. it. N atura, persona, mistica. Per una ricerca cristiana della verità, trad. it. di T. Franzoni, M. D'A mbra e A. M. Pezzella, a cura di A. Ales Bello, Città Nuova, Roma 1999.

A usdemLebeneinerjüdischenFamilie (ESW VII), Herder, Freiburg i. Br. 1987, trad. it. Storia di una famiglia ebrea. Lineamenti autobiografici: I'infanzia e gli anni giovanili, Città Nuova, Roma 1992.

Einführung in die Philosophie (ESW XIII), hrsg. von L. Gelber und M. Linssen, Herder, Freiburg i. Br. 1991, trad. it. Introduzione alla filosofia di A. M. Pezzela, pref. di A. Ales Bello, Città Nuova, Roma 1998.

Briefean Roman Ingarden 1917-1938 (ESW XIV), Einleitung von H. B. GerlFalkovitz, Anmerkungen von M. A. Neyer, hrsg. von L. Gelber und M. Linssen, Herder, Freiburg i. Br. 1991, trad. it. Lettere a Roman Ingarden, trad. it. di E. Costantini e E. Schulze Costantini, Libreria Editrice Vaticana, Città del Vaticano 2001.

Potenz und A kt. StudienzueinerPhilosophie des Seins (ESW XVIII), bearbeitet 
und miteinerEinfürungversehen von H. R. Sepp, hrsg. von L. Gelber und M. Linssen, Herder, Freiburg i. Br. 1998, trad. it. Potenza e atto. Studi per una filosofia dell'essere, trad. di A. Caputo, pref. di A. Ales Bello, Città Nuova, Roma 2003.

2. By others on Edith Stein and Empathy:

Albiero, Paolo and Matricardi Giada, Che cos'è l'empatia, Carocci, Roma, 2006.

Ales Bello, Angela, Empathy, a return to reason, in The self and the other. The irreducibile element in a man. Part I, ed. by A. T. Tymieniecka, Dordrecht-Boston, Reidel Publishing Company, in «A nalecta Husserliana», 6 (1977), pp. 143-149.

- Edith Stein: da Edmund Husserl a Tommaso D'A quino. In M emorie D omenicane, n. 7, n.s., 1976.

- Edmund Husserl e Edith Stein. La questione del metodo fenomenologico, in «Acta Philosophica», 1 (1992), pp. 167-175.

- Fenomenologia dell'essere umano - Lineamenti di una filosofia al femminile, Città Nuova, Roma 1992.

- A nalisi fenomenologica della volontà. Edmund H usserl ed Edith Stein, in «Per la filosofia», 1994, n. 31, pp. 24-29.

- Lo studio dell'anima fra psicologia e fenomenologia in Edith Stein, in Sogno e mondo, Edizioni Scientifiche Italiane, Napoli 1995, pp. 7-25.

- $\quad$ Edith Stein. Invito alla lettura, Edizioni San Paolo, Milano 1999.

- $\quad$ Edith Stein, Piemme, Casale Monferrato 2000.

- Empatia e dialogo: un'analisi fenomenologica, in A. Dentone (a cura di), Dialogo, silenzio, empatia, Bastoni Editrice Italiana, Foggia 2000, pp. 65-85.

- L'universo nella coscienza. Introduzione alla fenomenologia di Edmund Husserl, Edith Stein, Hedwig Conrad-M artius, Edizioni ETS, Pisa 2003.

- Persona e Stato in Edith Stein in D'Ambra, Michele(a cura di), Edith Stein. U na vita per la verità, «Quaderni dell'AIES», n. 1, Edizioni OCD, Roma 2005.

- Edith Stein: lo spirito umano in cammino verso la santità in D'A mbra, Michele(a cura di), Edith Stein.Lo Spirito e la santità, «Quaderni dell'AIES», n. 2, Edizioni OCD, Roma 2007.

Alfossi, Maura. et al., Guarire o curare? Comunicazione ed empatia in medicina, La Meridiana, Molfetta (BA), 2008.

Balzer, Carmen, The Empathy Problem in Edith Stein, in Huusserlian Phe- 
nomenology in a N ew Key. Intersubjectivity, Ethos, the Social Sphere, H uman Encouter, Pathos, ed. by A. T. Tymieniecka, Kluwe A cademic Publisher, Dordrecht-Boston-London, in «A nalectaH usserliana», 35 (1991), pp. 271-278.

Baron-Cohen, Simon., La scienza del male. L'empatia ele origini della crudeltà, Cortina, Milano, 2012.

Bellingreri, A ntonio, Per una pedagogia dell'empatia, Vita ePensiero, Milano, 2005.

Bettinelli, Carla,Il pensiero di Edith Stein. Dalla fenomenologia alla scienza della Croce, Vita e Pensiero, Milano 1976.

- II problema dell'Einfülung, in «Hermeneutica», 9 (1989), pp. 291304.

- La fen omen ologia, uno sguardo sulla verità, in «Aquinas», 37 (1994), pp. 377-386.

- L'itinerario di E dith Stein: dalla psicologia alla metafisica, alla mistica, in «Letture», 32 (1997), pp. 505-524.

Boella, Laura and Buttarelli A nnarosa,Per amore di altro. L'empatia a partire da Edith Stein, Raffaello Cortina Editore, Milano 2000.

- Grammatica del sentire. Compassione, Simpatia, Empatia, CUEN, Milano, 2004.

Bonino, Silvia, et al. (a cura di), Empatia. I processi di condivisione delle emozioni, Giunti, Firenze, 1998.

Bronzino, Cristina, Sentire insieme. Le forme dell'empatia, ArchetipoLibri, Bologna, 2010.

Challita, Marie, The empathic brain as the neural basis of moral behaviour Presented from interdisciplinary perspectives, DissertatioadDoctoratum in FacultateBioethicæPontificiiA thenæ Regina A postolorum, Rome 2014.

Cerri Musso, Renza,La pedagogia dell'Einfühlung. Saggio su Edith Stein, La Scuola, Brescia, 1955.

Costantini, Elio,Einfühlung und Intersubjektivitätbei Edith Stein und bei H usserl, in The Great Chain of Being and Italian Phenomenology, in «A nalectaH usserliana», 11 (1981), pp. 335-339.

- $\quad$ E dith Stein. Profilo di una vita vissuta alla ricerca della verità, Libreria Editrice Vaticana, Città del Vaticano 1987.

- $\quad$ Note sull'empatia nell'approccio interpersonale, in «Aquinas», 30 (1987), pp. 135-140.

- L'empatia, conoscenza dell'"Io" estraneo, in «Studium», 86 (1990), pp. 73-91.

D'A mbra, Michele,Il mistero e la persona nell'opera di Edith Stein, in «Aquinas», 34 (1997), pp. 581-591. 
D'Ippolito, Maria Bianca,L'analisi fenomenologica dell'anima, in«Aquinas», 41 (1997), pp. 61-67.

De Waal Frans., L'età dell'empatia. Lezioni della natura per una società più solidale, Garzanti, Milano, 2011.

Di Muzio, Luigi Carlo,I giorni della verità. La vicenda di Edith Stein, La sorgente, Vicenza, 1974.

Epis, Massimo,lo, anima, persona nella fenomenologia di Edith Stein, in «Teologia», 27 (2000), pp. 52-70.

- Fenomenologia della soggettività, LED, Milano 2003.

Fidalgo, Antonio,Edith Stein, Theodor Lipps und die Einfühlungsproblematik, in R. L. FETZ - M. RATH - P. SHULZ(hrsgg.), Studien zur Philosophie von Edith Stein - Internationales Edith-Stein-Symposion Eichstätt 1991, in «Phänomenologische Forschungen», 26/27, 1993, pp. 90-106.

Fortuna Federico, Tiberio Antonio, II mondo dell'empatia. Campi di applicazioni, Franco Angeli, Milano, 2001².

Freedberg David and Gallese Vittorio, Movimento, emozione ed empatia nell'esperienza estetica. In Teorie dell'immagine. II dibattito contemporaneo, a cura di Pinotti, Andrea and Somaini Antonio Cortina, Milano, 2009.

Galeazzi, Umberto., La lezione di Husserl nell'itinerario di ricerca di Edith Stein, in «Hermeneutica», 1989, n. 9, pp. 363-384.

Galofaro, Joseph,La tesi di lau rea sull'empatia, in «Rivista di Vita Spirituale», 41 (1987), pp. 255-261.

Gamarra, Daniel, Edith Stein: il problema dell'empatia, in «Divus Thomas», 91 (1988), pp. 181-189.

Geiger, Mattis, Sul problema dell'empatia di stati d'animo, in Besoli, Stefano and Guidetti, Luca, (a cura di) II realismo fenomenologico. Sulla filosofia dei circoli M onaco e Gottinga, Quodlibet, Macerata 2000.

- Essenza e significato dell'empatia, in Pinotti, Andrea (a cura di) Estetica ed Empatia. A ntologia, Guerini e associati, Milano. 1997.

Ghigi, Nicoletta, L'orizzonte del sentire in Edith Stein, Nimesis, MilanoUdine, 2011.

Giusti, Edoardo and Locatelli, Maura, L'empatia integrata. Analisi U manistica del comportamento motivazionale nella clinica e nella formazione, Sovera, Roma 2000.

Giordano, Maria, Ripensare il processo empatico, Franco Angeli, Milano, 2004.

Herbstrith, Waltraud,Edith Stein: una donna per il nostro secolo, Vita e Pensiero, Milano 1971.

Hoffman, Martin,Empatia e sviluppo morale, II Mulino, Bologna, 2008. 
Hughes, John,E dith Stein's Doctoral Thesis on Empathy and the Philosophical Climate from which emerged, in «Theresianum», 36 (1985), pp. 455484.

Kohut, Heinz,Introspezione ed empatia: raccolta di scritti (1959-1981) (a cura di) A. CARUSI, Boringhieri, Torino, 2003.

Körner,Reinhard,L' Empatia nel senso di Edith Stein. Un atto fondamentale della persona nel processo cristiano della fede, in SLEIMAN J. - L. BORRIELLO (edd.), Edith Stein. Testimone di oggi profeta per domani, atti del Simposio Internazionale, Teresianum (Roma) 7-9/ 10/ 1998, Libreria Editrice Vaticana, Città del Vaticano 1999, pp. 159-180.

Lavigne,Jean François,D a H usserl a Tommaso D 'A quino: Ia nozione di anima in Edith Stein in BUCARELLI M. - D'A mbra, Michele (a cura di), Fenomenologia e personalismo, Edizioni Nuova Cultura, Roma 2008.

Lombardo, Gaetano, Edith Stein, il problema della coscienza tra empatia e interiorità, tesi di Laurea (July 7, 2009), Università degli studi di Messina, Italy.

Manganaro, Patrizia, L'Einfühlung nell'analisi fenomenologica di Edith Stein, in «Aquinas», 43 (2000), pp. 101-121.

- $\quad$ Empatia, Messaggero di S. Antonio Editrice, Padova 2014.

Pancaldo, Diego,L'amore come dono di sé. A ntropologia filosofica e spiritualità in Edith Stein, Pontificia Università Lateranense, Roma 2003.

Paolinelli, Marco,A ntropologia e "metafisica cristiana" in Edith Stein, in «Rivista di Filosofia Neoscolastica», 93 (2001), pp. 580-615.

- $\quad$ N atura, spirito, individualità in Edith Stein, in D'A mbra, Michele (a cura di), E. Stein. Lo Spirito e la santità, «Quaderni dell'AIES», n. 2, a cura di Miche le D'ambra, Edizioni OCD, Roma 2007.

Pezzella, Anna Maria, Edith Stein fenomenologa, in «Aquinas», 37 (1994), pp. 359-365.

- $\quad$ Edith Stein e la questione antropologica, in «Per la filosofia», 17 (2000), n. 49, pp. 39-45.

- L'antropologia filosofica di Edith Stein - indagine fenomenologica della persona umana, Città Nuova, Roma 2003.

Pinotti, Andrea, (a cura di) Estetica ed Empatia. Antologia, Guerini e associati, Milano. 1997.

- Storia di un'idea da Platone al postumano, Laterza, Roma-Bari, 2011.

Rainone, Antonella, La riscoperta dell'empatia. A ttribuzioni intenzionali e comprensione della filosofia analitica. Bibliopis, Napoli, 2005.

Rifkin,Jeremy, La Civiltà dell'empatia. La corsa verso la coscienza globale nel mondo in crisi. Mondadori, Milano, 2010. 
Scherini, Marisa,Le determinazioni del finito in Edith Stein. La natura, il vivente, I'uomo, Edizioni OCD, Roma 2008.

Schulz, Peter,Il concetto di coscienza nella fenomenologia di E. Husserl e E. Stein, in «Aquinas», 39 (1996), pp. 291-305.

Secretan,Philibert,II problema della persona in Edith Stein, in MELCHIORRE V. (a cura di), L'idea di persona, Vita e Pensiero, Milano 1996, pp. 325-341.

Sinagra, Rosa, Empatia: la chiave di Edith Stein. Soggetto femminile in bioetica, Falco editore, Cosenza, 2006.

StuberKarsten, L'empatia, II Mulino, Bologna, 2010.

Tommasi, Francesco Valerio,Lo sviluppo del dibattito fenomenologico: idealismo e realismo nel pensiero di Edith Stein, in«Aquinas», 45 (2002), pp. 171-186.

Trentini, Cristina, Rispecchiamenti. L'amore materno e le basi neurobiologiche dell'empatia, II Pensiero Scientifico Editore, Roma, 2008.

Trevarthen, Colwyn, Empatia e biologia. Psicologia, Cultura e N euroscienze, Cortina, Milano, 1998.

Vanni Rovighi, Sofia,La figura e l'opera di Edith Stein, in «Studium», 60 (1954), pp. 554-568.

Vigone, Luciana,Introduzione al pensiero filosofico di Edith Stein, Città Nuova, Roma $1991^{2}$.

Worringer, Wilhelm, A strazione e Empatia. U n contributo alla psicologia dello stile, nuova edizione (a cura di) Pinotti, Andrea, Einaudi, Torino, 2008. 